\title{
Competing Sociological Diagnoses of Contemporary Times: Potentials of the RISU Conceptual Framework
}

\author{
Nikolai Genov ${ }^{1}$ \\ ${ }^{1}$ School of Advanced Social Studies, Nova Gorica, Slovenia \\ Correspondence: Nikolai Genov, School of Advanced Social Studies, 19, Gregorciceva St.,5000 Nova Gorica, Slovenia.
}

Received: November 30, 2015

Accepted: December 14, 2015 Available online: December 17, 2015

doi:10.11114/ijsss.v4i1.1256

URL: http://dx.doi.org/10.11114/ijsss.v4i1.1256

\begin{abstract}
The global financial and economic crisis caught social scientists and decision makers by surprise. They did not possess explanatory and predictive conceptual frameworks needed for coping with the crisis. This finding provokes critical analysis of available sociological concepts and constructive argumentation in three steps. First, disparities are identified between influential diagnoses of global processes and the processes themselves. Second, the question arises: How to conceptually reduce the global over-complexity in order to reach a reliable diagnosis of our times? Third, the suggested solution focuses on the substantiation, development and application of mutually connected concepts of four global trends: upgrading the rationality of organizations, individualization, spread of instrumental activism and universalization of value-normative systems (the RISU conceptual framework). The claim is that these trends decisively shape the contemporary social reality and will continue to profoundly shape it in the future. The conclusion reads that the RISU conceptual framework offers analytical tools for making the global, regional and societal over-complexity transparent for descriptions, explanations, forecasting and potentially efficient management of social development. The claim is substantiated by applying the conceptual framework in the analysis of the housing crisis in the United States.
\end{abstract}

Keywords: global crisis, methodological societalism, methodological globalism; global trends

\section{Introduction}

In critical social situations some local or otherwise negligible events tend to receive global relevance at least symbolically. The beginning of the worldwide financial and economic crisis in 2008 was marked by a number of such events. Some of them revealed the very high level of interconnectedness and complexity already reached in the transnational economic, political and cultural space. Others exemplified the difficulties facing the conceptual efforts to put precise diagnoses on the ongoing processes. Still others offered illustrations of diagnoses which - intentionally or not - did not correspond to reality as claimed. In the end effect, imperfect or false diagnoses and prognostications make the efficient coping with practical challenges difficult or impossible.

A telling example of failed diagnoses and prognostication is offered by the outlook of the global economic situation published by experts of the International Monetary Fund in October 2008. The experts stressed the accumulation of global economic uncertainties but forecasted a global economic growth of $3 \%$ in 2009. The year was expected to become the turning point towards global economic recovery (World Economic Outlook 2008, 2008: 1). In reality - few exceptions notwithstanding - 2009 became a critical year for the vast majority of national economies in the world. The decline of the global output reached $-0.6 \%$ (World Economic Outlook 2010, 2010: 2). World economy moved into a deep recession. The diagnosis and prognostication made in the autumn of 2008 were impressively falsified by the global processes.

One may interpret this development as a simple falsification of experts' prognostication. This is normality in science, the applied science including. The negative outcomes in testing scientific hypotheses are not less valuable than the verification of hypotheses. However, the falsification of some diagnoses and prognostications has far reaching practical implications as it is usually the case with the diagnoses and prognostications of the IMF experts. This is why there are scientific and practical grounds to specially ask for the reasons of the IMF expert's failure. There is no evidence that they have intentionally made public a positive forecasting in the autumn of 2008 in order to manipulate decision-makers and the public at large. Most probably, the major reason was the neglect of available knowledge about the effects of the distorted balance of exports of goods and services and the trans-border financial flows. The pathological over-expansion of financial transactions was recognized as a factor negatively influencing all other economic balances, but the long-term 
destructive effects of the bubble-like financial transactions were both conceptually and empirically underestimated as a rule.

In other cases there is strong empirical evidence that influential public statements were really guided by intentions to manipulate the public opinion and the decision-making of numerous influential actors. One widely cited interview of the - then - US Secretary of Treasure Henry Paulson is an easily provable case of this type. The interview was given to the mass media the day after the bankruptcy of the US American Lehman Brothers bank in September 2008. Referring to the event, Paulson stressed 'the soundness and the resilience of our (US American - the author) financial system' (MarketWatch, 2008). Two years later the reader could learn from Paulson's memoirs that during the same day he thought in entirely different terms. He had been frightened by the awareness that both the US American and the global financial systems were on the brink of collapse (Paulson, 2010).

European politicians used to repeat the same pattern of public statements spreading misleading optimism. Ten days after Paulson's interview the - then - German Minister of Finance Peer Steinbrück delivered a strategic speech before the Bundestag. He claimed that 'the financial crisis is above all an American problem' since the crisis was caused by financial speculations in the United States (The Telegraph, 2008). Later it became known that at the time of Steinbrück's speech the governments of the most powerful economies, the German government including, were already positioning themselves for the immediately forthcoming first G20 summit. The clearly formulated task of the summit was to handle the looming global financial and economic crisis (Bradford \& Linn, 2011).

Thus, one has to ask himself/herself about the reasons for the obvious disparity between statements and realities in the historical autumn of 2008. Was the disparity mostly caused by difficulties in establishing the truth about complex and complicated global interconnectedness and processes? Or, was the disparity mostly caused by intentions to camouflage the risks and to camouflage the camouflaging? The realistic answer should certainly recognize that both factors were at work. Various types of interconnectedness in the transnational economic and political spaces have reached the point where it was and it is difficult to disentangle causes, processes and effects of globally relevant events. Efforts to achieve this are being made additionally difficult by interests of powerful groups, organizations and governments to hide their real interests, intentions and actions. As a result, actors in the transnational social spaces face more and more differentiated structural constraints in their efforts to cope with the over-complexity both in cognitive and practical terms. It is getting increasingly difficult to make the ongoing processes transparent despite the tremendous amount of available information and the sophisticated methods of collecting, processing and using it.

The barrier of over-complexity might be the major explanation for the very rare or usually missing corrective interventions of sociologists in the public discourse on intentional or unintentional misrepresentations of global processes. However, the absence of sociologists from the efforts to identify achievements, problems and developmental trajectories of the present day global society is not a flattering indicator for the maturity and the relevance of the discipline. Its social influence used to be best recognized by attempts of leading sociologists at putting diagnoses of the times in critical situations of change (Mannheim, 1947; Beck, 1986; Schimank \& Volkmann, 2007).

The conclusion is that there is an obvious need to approach the present-day over-complex transnational social spaces and the multidimensional interplay of economic, political and cultural factors in these spaces by using new conceptual tools. The starting point for materializing the intention is the analysis of complex and complicated social structures and processes which are making the diagnostic and prognostic tasks so challenging.

\section{Controversial Processes in the Transnational Spaces}

There is a major stumbling-block in the way of resolving the task to conceptually reduce the over-complexity of transnational economic, political and cultural processes. The stumbling-block is the large variety of their interconnected causes and effects. There is a perplexing difference between what is visible on the surface of events and what structurally underlies them. On the surface, the technological division of labor has reached a striking global diversity. Inventions and their technological applications migrate over the globe. Production lines move from one part of the world to another. Assembly lines receive supplies from hundreds of international subcontractors. The transport infrastructure on the surface, water and in the air follows the growing geographical diversification of production and trade (Narula, 2014).

Though, below the surface of the diversification of production and services one may discover a tremendous concentration in key components of the division of labor. The concentration concerns the production of knowledge first of all. It is globally organized like all other profitable industries. Huge investments support the research and development in only few leading centers of each type of knowledge production. The competition between these global centers is fierce. Only the best funded and most efficient companies can afford keeping the pace in the competition. Besides the tremendous financial resources the successful research and development requires long-term accumulation of human capital and development of sophisticated organizational management (Serapio \& Hayashi, 2004). The leading companies in the production and application of break-through knowledge can reckon on immense profits. Elaborated legal regulations and institutional mechanisms of protecting intellectual property rights make the spread of cutting-edge knowledge difficult. 
Contrary to the ideals of Enlightenment envisaging knowledge as a common good, the newly acquired intellectual achievements in fundamental and particularly in applied science are being privatized as a rule and kept secret in only few centers of knowledge production worldwide.

The patents statistics impressively illustrates this astonishing concentration of knowledge production together with some shifts in the location of leading innovators. The shifts have profound geopolitical consequences. It is telling to notice that in 2014 among the 20 most active business applicants for patents 12 were from Japan, China and South Korea. From the rest 4 companies were from the United States, 2 from Germany and 1 from each Sweden and the Netherlands (WIPO PCT Yearly Review 2015: 44). The data reveals a geopolitical shift on the top of the division of the most highly qualified labor from North America and Western Europe to East Asia. The shift has far-reaching economic, political and cultural implications. It is impossible to identify or imagine all of them in their entirety at present. One may only notice that the fundamental change in the technological and consequently in the economic global leadership took place in an evolutionary way and below the surface of the widely debated economic, political and cultural events.

It was exactly in the same evolutionary and hardly noticeable way that the worldwide financial flows increasingly disconnected themselves from the international trade with goods and services. The ensuing fierce speculative chasing of hot money by investment banks, hedge-funds, pension funds and other major investors were identified as the key factor having provoked the financial crises in Asia, Russia and Argentina. They revealed a shift towards speculation with toxic papers of financial derivatives. Their "value in exchange" has peripheral relation to their value in use in production and consumption. Few experts paid attention to the long-term consequences of the new speculative economic over-complexity until the implosion of the global finances in 2008. The growth before the crisis was mostly driven by the excessive financial exchanges disconnected from the stagnant real economy (Shiller, 2012: 178f.). In fact, the volume of the foreign direct investments grew between 1992 and 2007 more than ten times mostly due to the short-term speculative financial flows (World Bank Database 2012a). The volume of exports of goods and services rose by only 10 percent during the same period (World Bank Database 2012b).

The disconnection of financial exchange from the real economy became possible under the conditions of triumphant economic deregulations. Since September 2008 panic driven efforts at macro-regional and global level have aimed at establishing national, macro-regional and global transparency of the financial flows and at introducing regulations in the area. The short-term goal is to ameliorate the devastating effects of the global financial crisis which immediately evolved into global economic crisis. The long-term aim is to timely identify the symptoms of financial and economic crises and to prevent them of becoming destructive on the large scale as this happened in 2008 and 2009.

Although the need for some regulations of the global financial exchange was recognized already in the initiative for Tobin tax, there were no serious efforts to introduce any regulation before the global crisis. The reluctance was not the result of the lack of will or only motivated by specific interests. The crisis made obvious that both the regional (ASEAN, EU, MERCOSUR, NAFTA) and particularly the global political integration dramatically lags behind the already achieved high level of technological and economic integration (Suter \& Herkenrath, 2012). On many specific occasions the activities of UNO and the related organizations aiming at crisis management turned out to be too small-scale or came too late if indeed. The global government seems to be the only alternative but it is obviously out of reach at present. The fears that one global actor or several powerful countries might dominate it and thus to undermine the seemingly multipolar world are too strong.

Given the absence of other organizational schemes tentatively performing the functions of world government, the most efficient mechanism of concerted efforts for coping with the global financial and economic crisis turned out to be the summits of G20. The first one took place in November 2008 when the global character of the financial and economic crisis was already undeniable. As compared with the highly elitist G7 (or G8), G20 seems to represent a larger variety of interests of the global population. At the first glance this is an opening of the global political decision-making to representativeness and legitimacy, organizational efficiency and transparency (Bradford \& Lim, 2011; Kirton, 2013). A closer look at the phenomenon reveals the same deep problems with transparency characterizing the global division of labor and the global financial transactions. Who has actually selected and appointed the 19 countries with the largest GDP in the world plus the European Union to represent the interests of the global population? Whatever the answer might be, there is an obvious lack of democratic legitimacy of the body. It has not been selected and elected in any transparent democratic way. It is practically not responsible before anybody. To make the issues about the democratic transparency even more complicated, the discussions of G20 usually take place behind closed doors. But some outcomes of these discussions have existential implications for large parts of the world population or for the human civilization indeed.

This variety of organizational, political and moral issues in the transnational spaces might provoke the temptation to see the clear economic, political, cultural and military divisions and dependencies during the Cold War as preferable. There are no serious reasons for such assumption. The divisions and the integration schemes during the Cold War were based on 
the balance of terror. It reached the brink of catastrophic derailing several times during the period. The very philosophy of Cold War's transnational order belongs to history since it represented an extreme version of the outdated Westphalian rule cuius regio, eius religio. It does not apply any more. Mixtures of racial, ethnic and religious groups are widespread. Trans-border migrants are everywhere. A global clash of civilizations may not come about but clashes of different and opposite values and norms do take place every day in all parts of the world. The transmission of information for both peaceful cultural coexistence and cultural confrontation by means of advanced global communications makes the world getting smaller but also too complex and open to a variety of uncertain futures (Delaney, 2009). Thus, the task for analytical cognitive reduction of the global over-complexity becomes more urgent that ever. Some lessons from previous influential efforts of sociologists to resolve the issue might be helpful in handling it under the present day conditions.

\section{Two Sociological Attempts at Reducing the Social Over-complexity}

Some forty years ago Talcott Parsons attempted a concise sociological diagnosis on his contemporary times. He still had to deal with the Cold War polar political and military division of the world. For the purposes of the sociological diagnosis he interpreted the transnational social space during the sixties of the twentieth century as a systemic whole ('system') of societies. 'Society' was defined in socially-universal Aristotelian analytical terms as 'the type of social system characterized by the highest level of self-sufficiency' (Parsons, 1971: 8). The so defined building blocks of the world order were the nation-states. Parsons believed that the value-normative and organizational patterns of the societies divided by the Cold War and its consequences were changing in the direction of future convergence. He put a precise diagnosis of the functional requirements for change of the Soviet-type societies. But he could not foresee the emergent features of the convergence which currently produces and reproduces the global over-complexity and contradictions we are confronted with. The major reason for the limitations of his prognostic efforts was the linking of his conceptual tools to the structural and functional characteristics of societies alone. The transnational social space was for him still the space of international relations between societies. Parsons did not develop and apply ideas of "world society" or "global society" as later assumed (Stichweh, 2005).

The currently achieved global interconnectedness questions the productivity of Parsons' methodological societalism. It is intrinsically related to the development of modern nation-states with their enabling and constraining potentials in economy, politics and culture. The nation states remain quite relevant in all present-day structural levels of social interaction and in all action fields, the local management of the global crisis including (Reinhart, 2013). But the relative relevance of societal systems in social interactions has declined in the course of the progressing globalization (Farrar \& Mayes, 2013). The currently well differentiated and integrated transnational spaces have different enabling and constraining qualities as compared to the situations which Parsons could analyze. Consequently, new conceptual tools are needed given the new conditions and aims of the sociological analysis. The search for conceptual tools may follow Parsons' idea to rely on concepts framing his functionalist analysis of ancient, medieval and modern societies. For this purpose Parsons introduced universalized analytical concepts of differentiation, adaptive upgrading, inclusion and value generalization in order to strengthen the diachronic analytical potential of his functionalist conceptual framework AGIL. However, he only partly moved in the promising direction of developing and applying new analytical concepts particularly relevant for the study of social change and development. Most probably, they should have referred to social processes first of all (Turkel, 2005). These concepts had to support Parsons strategic turn towards the explanation of social evolution by overcoming the explanatory limitations of his major paradigm based on the concept of societal systems. Well elaborated and applied analytical concepts of social processes would better serve the efforts to explain social change and development than the concept of functionally differentiated social systems.

In contrast to Parsons' analytical focus on societies and to his functionalist analytical conceptual scheme for systemic analysis of historical realities, Immanuel Wallerstein laid the stress on direct historical studies. He defined his methodological approach as 'embedded in the history of the modern world system' (Wallerstein, 2004: 1). Guided by this historically focused methodological approach he identified a sequence of historical versions of world systems. According to him they have consequently evolved after the emergence of the world-wide division of labor and markets since the sixteenth century. The first version of world system he identified is defined by the domination of the Netherlands, the next one by the British domination and the present day world system is defined as dominated by the United States. In specific historical constellations these three countries and their close allies are presented as the core of the respective world systems. In Wallerstein's vision the rest of the world has been divided into semi-periphery and periphery since the appearance of world systems. The historically specific semi-periphery and periphery have fluctuating characteristics and borders.

Thus, following some substantive ideas of Marx and methodologically influenced by Max Weber's study on the emergence of modernity in Western Europe, Wallerstein sees his cognitive task in the analysis of changing historical constellations. But unlike Weber Wallerstein aims at reproducing the structure and dynamics of the world-wide relationships and processes of domination and exploitation after the emergence of world systems. This approach is basically innovative and potentially productive. In the same time, it might be seen as a step back from the achievements of 
Parsons in developing and applying universalized social science concepts. Christopher Chase-Dunn clearly identified the implications of Wallerstein's methodological decisions: 'Universalistic theoretical explanations were rejected and the historicity of the social science was embraced' (2006: 589). Wallerstein's stress on historical interpretations makes the systematic historical explanations and comparisons strategically rather difficult if not impossible. In his voluminous publications he repeatedly insists on the point that the development of the world systems after the XVI century has come as the result of historical continuity and historical change. However, how can they be explained without analytical concepts bridging the studies on continuity and change? The lesson is that the reference to historical constellations in Wallerstein's methodological globalism should be consistently followed but by enriching the historical analysis with systematic explanations guided by analytical conceptual frameworks.

Thus, two fundamental issues appear in the theoretical context under scrutiny. First, the present day full-fledged globalization has much deeper historical roots than Wallerstein's interpretation of world-systems suggests. The globalization of human activities actually started with the migration of the first group (or groups) of homo sapiens from Africa and with the spread of the species around the world. Therefore, facts related to long-distance communication, trade and conquer already in the pre-historic and ancient times should be carefully taken into account in the empirical research and theoretical considerations concerning the present day global system. Second, the implication is that the development of universal patterns of social structures and processes in primitive and ancient societies should not be underestimated in the theory building and in the explanatory application of theories in the study of contemporary societies and their involvement in the functioning and development of the world social system.

This rather complex and complicated substance has to be conceptually "sliced" in order to make meaningful descriptions, explanations and prognostications of the present-day transnational social structures, functions and processes possible. This will be further done by focusing on the concepts of four global trends. The guiding assumption is that they can successfully serve as analytical tools for the conceptual "slicing" of the over-complex historical reality.

\section{Four Global Trends}

The suggested methodological approach for resolving the above task does not follow the usual concentration of sociological studies on global systems, structures and functions. Instead, the selected focus is on the historical roots, present day manifestations and prospects of global social trends. Thus the approach aims at avoiding the mono-dimensionality of most conceptual frameworks used for diagnoses of our times by stressing the contemporary specifics of communications, environmental problems, or rationalization (Schimank \& Volkmann, 2007). The guiding assumption of the following conceptualizations reads that four global trends have shaped the present day global society and determine its present day controversial paths into the future.

The starting point of the argumentation is the historical fact that from their evolutionary appearance on Earth human beings have continuously developed and improved varieties of informal and later formalized social organizations. This applies to the evolution of the organization of the division of labor first of all. Its most primitive patterns are based on differences of sex and age. The achievements of the present day division of labor are impressively exemplified by the thousands of occupations defined in legally binding terms by the US American Bureau of Labor (Standard Occupational Classification 2010). Another action field in which the progressing differentiation and sophistication of organizational patterns started early in human history is the area of preparing and implementing of warfare. Military organizations reached high level of precision and efficiency already in ancient times (Roth, 2012). The organizational evolution of political life started from simple power hierarchies based on physical strength or clan relations in primitive societies. Currently we are aware of the variety of historical patterns of democratic, semi-democratic and non-democratic political organization (Wilson, 1995). Spiritual life has also experienced organizational evolution in history from the primitive worshipping to the sophisticated organization of churches, sects and religious movements in present day societies (Torry, 2005).

There is one major common feature of the historical phenomena mentioned above. This is the trend of permanent improvement of the organizational patterns. In other words, this is the trend of upgrading the rationality of organizations. The trend is perfectly documented in the tremendous achievement in organizational development of state organization starting from the Hammurabi's Code (Richardson, 2004) and reaching the processes in the present day sophisticated state institutions. The upgrading of organizational rationality basically takes place in two directions. On the one hand, the cognitive background of organizational decisions and implementation of decisions is getting more differentiated and better substantiated throughout history. On the other hand, as a result, organizational decisions, their implementation and outcomes are getting increasingly efficient and effective (Scott and Davis 2007). Both statements do not imply any idea of teleological or mono-linear upgrading of the rationality of organizations throughout history. To the contrary, cases of shrinking or lost cognitive resources needed for the rationality of organizational decisions and actions as well as of declining organizational efficiency and effectiveness are abundant in human history. Nevertheless, human beings and 
their organizations are able to learn, to preserve, improve and apply the lessons from successful and failed trials to resolve problems, to overcome declines in organizational efficiency, and thus to achieve higher level of rationality of the organizational patterns in the long run (Starbuck et al., 2008).

The key indicators for the study of upgrading the rationality of organizations cover three dimensions of organizational change: the actors involved in the change, the dynamics of their relations and key processes. What kinds of individual or collective, cooperative or hostile, conservative or radical, etc. actors might be identified in intended, attempted or achieved upgrading of organizational rationality (Hindess, 1989)? What kinds of domination or equality, affinity or animosity, cooperation or conflict, etc. characterize their relations (Due et al. 1999)? What kinds of processes like stagnation or change, differentiation or integration, long-term or short-term change, etc. predominate in the analyzed cases of upgrading (or degrading) the organizational rationality (Dahms and Hazelrigg, 2010)? The questions indicate that there is a large variety of modalities for upgrading the rationality of organizations or for the decline of organizational rationality.

The studies on the change of organizational patterns provide abundant evidence that one key component in the efforts for achieving the effect of upgrading organizational rationality is the mobilization of the human factor. The mobilization has two most major dimensions. First, individuals might find available or could manage to acquire more differentiated and larger social spaces for autonomous orientation, decision and action in organizational structures. On this basis the upgrading of the rationality of the organization under scrutiny increases, in some cases substantially. Second, the more the individuals participating in the process are motivated to improve their capacities for adequate autonomous orientation, decision and action, the more tangible is the upgrading of the organization under scrutiny.

Both processes of structural differentiation and enlargement as well as improvement of the capacities of individuals to master tasks, the tasks of structural change including, characterize the global trend of individualization. It has its historical roots in the upgrading of the rationality of organizations throughout human history. The trend of individualization is deeply rooted in the biological and social predisposition of individuals to learn and to apply the acquired knowledge and skills. In modern societies individualization is a particularly important social phenomenon. The reason is the increasing need of organizations to actively adapt to rapidly changing environments. The learning of individuals and their activity are getting more and more the decisive element in the management of organizational change (Beck \& Beck-Gernsheim, 2002).

The core clusters of indicators for the study of individualization are of three types. First, indicators about social-structural conditions for orientation, decision and action of individuals: To what extent is autonomous orientation of individuals under the given circumstances possible? To what extent is autonomous decision about individual action under the given circumstances possible? To what extent is autonomous action under the given circumstances possible? Second, indicators about the conditions of learning: Are the economic circumstances fostering or hindering the individual learning? Are the political conditions fostering or hindering the individual learning? Are the cultural circumstances fostering or hindering the individual learning? Third, indicators concerning motivation: Are the circumstances predominantly motivating individuals to escape from handling the challenges? Are the circumstances predominantly motivating individuals to reproduce the existing conditions? Are the circumstances predominantly motivating individuals to change the existing conditions?

When discussing the issue of motivation one has to pay special attention to the predominant patterns of thinking and behavior in the historical situation. There were periods in human history in which these patterns used to be strongly influenced by religious ultimate values guided by ideas about life after life and the salvation of the soul. Max Weber noticed that the widespread rigorous orientation towards following religious ultimate values during the European Medieval Ages was step by step replaced by in-worldly cultural orientations in the course of the European Reformation. Talcott Parsons further elaborated on the issue of secularization of action and registered the effects of the spread of instrumental activism. It is a value-normative orientation focused on money acquisition in the context of progressing commercialization of social relations and stress on consumption. In the present day global society this is the rapidly spreading and predominant pattern of thinking and behavior.

However, it is well known that even under the extreme institutional pressure of focusing on life after life the issues of material interests have always been of high relevance for the vast majority of the population. This particularly applies to the issues related with the quantity and quality of consumption. In this sense the spread of instrumental activism is not a new historical phenomenon at all. The strong predominance of this phenomenon in the present day commercialized societies has been evolutionary prepared by the orientation of human thinking and behavior towards material advantages and consumption throughout human history (Crichton, 2010).

The major clusters of indicators for identifying and measuring the spread of instrumental activism are the following: To what extent is the typical thinking and behavior under given historical circumstances focused on the ultimate values of 
religion or religion-like ideology? To what extent is the typical thinking and behavior under given historical circumstances focused on values of in-worldly material advantages? To what extent is the typical thinking and behavior under given historical circumstances framed by the focus on consumption?

The questions receive historical meaning after taking into account that societies throughout history have tended towards developing relatively homogenized value-normative systems. Most often they have been imposed as binding. This is understandable since value-normative universalization is the key for cultural integration of any society and thus crucial for its survival. Together with the continuing efforts for value-normative integration of societies we currently observe the spontaneous emergence of a value-normative system which is common for all advanced societies in its major features. The two pillars of the universalization of values and norms under these conditions are the idea of universal human rights together with the idea of sustainability. The universalization of both value-normative ideas is a new historical phenomenon only at the first glance. Various versions of human rights - at least for individuals belonging to a given clan, caste, tribe, society (Moyn, 2010) or having a specific religious affiliation (Joas, 2013) might be identified in all known historical circumstances. The same holds true for ideas and practices of the broadly understood sustainable environmental, economic, political and cultural development (Grober, 2012).

Three major clusters of indicators can measure the level of universalization of value-normative systems throughout human history and particularly nowadays: First, what kind of value-normative system (polytheist, monotheist, secular, etc.) is already predominant or tends to become predominant under given historical circumstances? To what extent is the value-normative system introduced or stabilized by force? Can this value-normative system play its integrative role in the long-run or not?

Thus, upgrading the rationality of organizations, individualization, spreading of instrumental activism and universalization of value-normative systems (RISU) are global trends having deep historical roots. Currently the four global trends are shaping the social reality and thus decisively determine its future social development (Genov, 2014). This is the background assumption of the use of the concepts of four global trends as a multidimensional framework of analytical tools for efficient cognitive reduction of the global over-complexity. ${ }^{1}$ This can be best done by taking into account the considerations underlying Figure 1:

-The shaping of each of the four global trends and their interaction is determined in every historical moment by natural, technological, economic, political and cultural conditions and the related institutional frames in the situation under scrutiny;

-The dynamics of each of the four global trends as well as of their interaction could be properly identified, explained and forecasted in the longue durée (Braudel, 1973; Braudel, 1980) of historical changes;

-The "long waves" of historical changes are marked by the emergence of new institutional frames, new conditions of action and thus of new characteristics of each of the global trends and of their interaction.

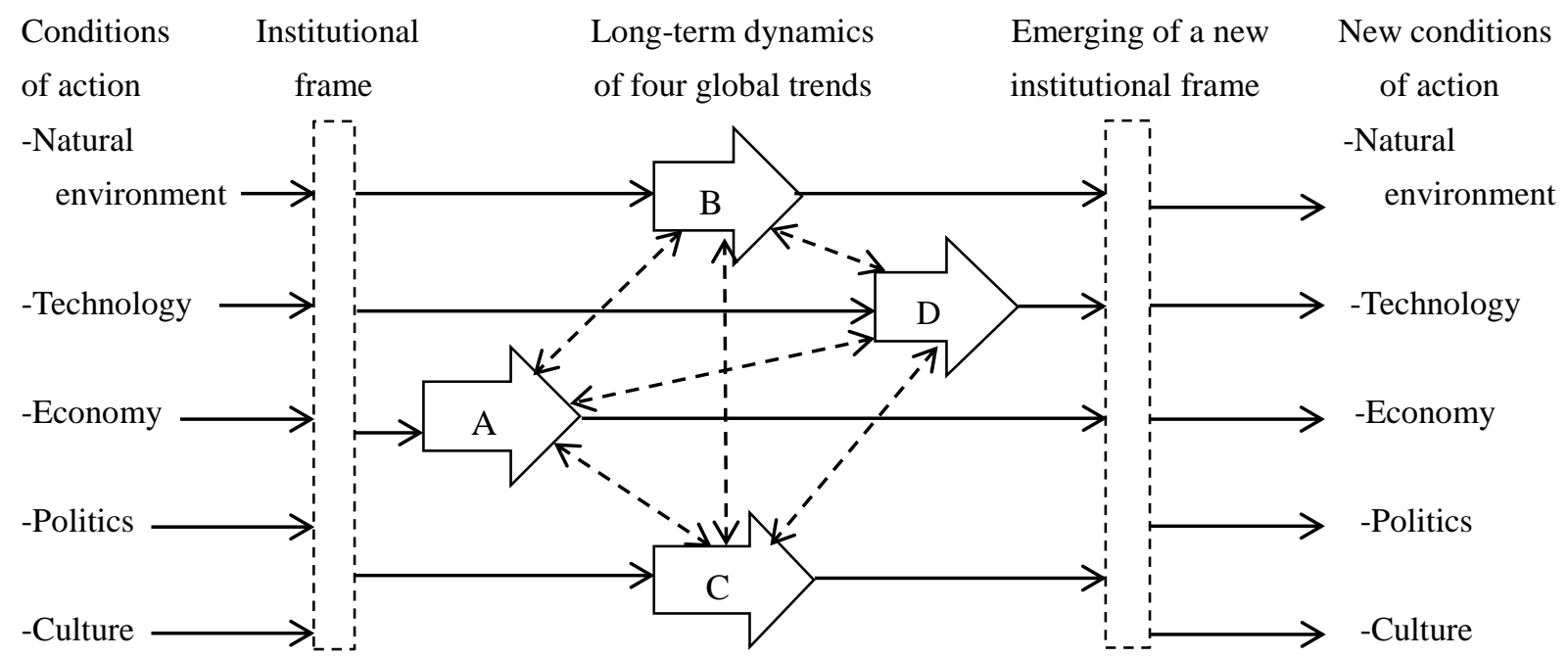

Figure 1. Four global trends in the longue durée

\footnotetext{
${ }^{1}$ The RISU conceptual framework can be only formally compared with the IEMP (ideological, economic, military and political sources of social power) conceptual model developed and used by Michael Mann (2013). Both conceptual schemes are entirely different in their substance.
} 
Legend:

A/ Upgrading the rationality of organizations
C/ Spreading of instrumental activism

Source: Author's design

\section{The Concepts of Four Global Trends as Analytical Tools}

The explanatory potential of the RISU conceptual framework will be further exemplified by the analysis of the collapse of the housing market in the United States. The case is particularly relevant since the collapse of the national housing market triggered the global financial and economic crisis in 2008.

Ad A/ Several US laws passed after the WWII used to foster the fulfillment of the American dream of house owning for low-income households. This philosophy was the backbone of the state policies for direct state support to the companies Fannie Mae and Freddie Mac. They played a key role in guaranteeing the housing mortgages. However, the motivation for this interventionist policy of both Democratic and Republican administrations was not philanthropic. Housing construction has been one of the key motors of economic growth in the country and had to be supported by tax-payers money. For banks and pension funds the financing of housing construction and the participation in the housing market has been a lucrative business for decades. The investment banks and hedge funds became largely involved in it as well. In order to attract additional funding the financial institutions increasingly wrapped their assets in the housing market in financial derivatives. The new financial instruments used to be regarded as a substantial step forward in the direction of upgrading the organizational rationality of the financial services to the housing industry. The efficiency of the so rationalized financial system seemed to be firmly guaranteed. The US financial institutions massively offered easy credits even to households which were not particularly reliable concerning the repayment of the housing mortgages. As a measure of precaution the financial institutions offered the mortgages with credit payment rates adjusted to the change of housing prices.

At the first glance these organizational developments seemed to be domestic and linked to the US economic cycle alone. In reality, they have increasingly become global developments due to the large scale foreign investments into US economy. During the relatively short period between 1990 and 2007 these investments skyrocketed from $\$ 200$ billion to $\$ 2200$ billion (Stratton 2010: 4). Basically, the opening of markets to foreign investments is rational in economic terms. Investments could flow to places where they are mostly needed and to be used in the most efficient way. Following this logic, foreign investors were particularly attracted by the booming American housing market. A large share of the financial activities of international investors was linked to transactions with derivatives of housing market shares.

This is the major reason why the US American subprime mortgage crisis immediately developed into a global financial crisis in 2008 and subsequently evolved into a global economic crisis. What seemed to be a rationalized system for financing the US national housing market by international investors turned out to be rather irrational in its speculative fundaments and in its consequences for the transnational finances. The effect was the tremendous drop of international investments in the US American property market in 2008. The foreign acquisition of apartments dropped from the worth of \$3,686 million in 2007 to $\$ 1,039$ million in 2008 (Stratton, 2010: 9).

Thus, the concept of the global trend of upgrading the rationality of organizations has its pendant in the concept of mechanisms and effects of degrading the rationality of organizations. The overarching concept of both processes is the upgrading of bounded organizational rationality. This concept helps the identification, explanation and prognostication of achievements and failures of actors, relations and processes implementing the global trend of upgrading organizational rationality. One can identify constructive advances of the trend but also unintended or intentional camouflaging or camouflaging of camouflaging of causes, processes and effects of critical organizational developments. The camouflaging is typically guided by vested interests of powerful actors. Taking the management of the recent financial and economic crisis as an example, one would discover mixtures of rationalities and irrationalities in the orientations, decisions and actions of key national and international actors. The criticisms on G20 are not focused on its ad hoc handling of fundamental problems of the global economy alone (Hazakis, 2012). In more radical criticisms G20 is regarded as being secretive and basically unable to take internationally binding decisions as well as to implement them. The criticisms clearly indicate that G20 is far from the rationalized organization which is very much needed for efficient political governance of global economic processes.

The unavoidable conclusion is that the causes of the crisis of 2008-2013 continue to be at work since there is no truly legitimate international body which would consistently and efficiently work for preventing these forces of from bringing about the next global financial and economic crisis. The recovering American housing market is already profitable and attractive. The international investments in American housing stabilized relatively fast after the crash (The Wall Street Journal, 2012). The IMF, G20, the European Union and national governments aim at reducing the 
uncertainty. But it is intrinsic to the longue durée of the global financial system.

Ad B/ Progressing individualization is a challenge to individuals, groups, organizations and societies. Influential opinions locate this challenge in the post-modern times alone (Bauman, 2001). In the context of our argumentation individualization is interpreted as a global trend having deep historical roots and manifestations in the development of the division of labor, economic activities, political participation and cultural achievements all over the history of human societies. Nevertheless, it is true that mostly due to the rise of the living standard and the democratization of political relations worldwide brought about historically unprecedented achievements in individualization (National Intelligence Council, 2012: 6f.). It is a blessing for millions. However, individualization always comes about with more and qualitatively new responsibilities for well substantiated and implemented action.

In the case of the American housing market individualization became problematic under multiple conditions and with multiple consequences. The need for facilitating individualization was in the background of the decisions of federal institutions to support the improvement of the housing conditions of disadvantaged segments of the American population. This support notwithstanding, the fulfillment of the American dream of home ownership could only be funded by home mortgages taken on a large scale by private households. Following the global trend of individualization, millions of Americans decided to sign contracts for housing mortgages with interest rates adjusted to the changing prices of housing. The prospects for accelerated individualization motivated bankers, managers of hedge funds, pension funds and other domestic and international investors to get actively involved in the highly profitable housing business. Therefore, both on the demand and supply side there was a strong interest on the part of individual actors to participate in the booming business with home mortgages. Their value skyrocketed between the years 2000 and 2005 from $\$ 4800$ billion to $\$ 8800$ billion (Statista, 2011).

The boom in housing construction and in home mortgages was a typical case of bounded rationality accompanied by numerous sources and manifestations of irrationality. The understandable desire cherished by millions of Americans for successful individualization in better housing brought about a huge credit bubble in the American economy. The collapse of the US-national housing bubble triggered the global financial and economic crisis. However, the crisis was triggered not by irrational demands of low income households alone. Another driving force of the credit bubble and the global crisis was the speculative generous supply of subprime home mortgages by individuals sitting in the headquarters of credit institutions or acting on their behalf. Millions of Americans lost their dream about housing ownership over night after having become unable to pay the interest rates of the housing mortgages adjusted to the speculative rise of the market value of housing. The debtors had to leave the homes. Nobody wanted to buy the abandoned homes despite the collapse of the housing market prices. The state-supported companies Fannie Mae and Freddie Mac could not guarantee the mortgages anymore and had to be nationalized in order to avoid financial catastrophe. Millions of Americans lost their jobs in the construction industry. Many smaller financial institutions went bankrupt together with the construction firms.

Using Michel Foucault's concepts, the massive loss of housing, jobs and income by millions of Americans came about as 'normalization'. The victims had to recognize the power of the financial and economic structures and their routine exercise of 'discipline and punish' (Foucault, 1991) non-rational thinking and behavior of participants in the American housing market. The spill-over effects of this crash of individualization in the United States reached many locations of the transnational social space and affected individualization in many other parts of the world. The processes provided abundant evidence for the point that individualization as a global trend is marked by deep internal controversies. It is exactly this rich content of the concept that makes it a powerful tool for identification, explanation and prognostication of crucially important processes in present day societies.

Ad C/ Numerous achievements of modern societies as well as of the present day global civilization are directly related to the spread of instrumental activism. However, it would be short-sighted not to see that the achievements in the commercial motivation and regulation of action as well as the present-day consumerism have long history. They have been prepared by centuries of efforts to free the markets from political and cultural obstacles and to achieve a high level of mass consumption. Therefore, the contemporary spreading of value-normative and behavioral patterns incorporating or supporting instrumental activism should be regarded as a tremendous civilizational achievement having deep roots in human history.

In the same time, the worldwide powerful spread of instrumental activism is the direct or indirect cause of profound irrationalities and related human suffering. The experience from the massive speculations on the US American housing market is a case strongly supporting the point. There was no other identifiable cause for the tremendous rise of housing prices between 2004 and 2006 in the country than the massive speculations with real estates (Bayer et al., 2011). The speculative rise of housing prices had immediate effects on the adjustable rate of mortgages. The monthly payments for principal and interests of median first-time buyer jumped from $\$ 750$ in 2001 to $\$ 980$ in 2005 (Garriga et al., 2005: 405). 
One of the major instruments for speculations was the fast increase in the financing of housing business by financial derivatives. They became less and less related to their basis in construction, selling or renting of housing. In the end effect the spread of instrumental activism via speculative financing of the housing market turned out to be full of irrationalities and potentially self-destructive. Karl Polanyi was certainly correct in his conclusion from the analysis of the marketization as core factor for the capitalist transformation of society: 'To allow the market mechanism to be sole director of the fate of human beings and their natural environment ... would result in the demolition of society' (2001 [1944]: 73). The crucial point in the case under scrutiny is that the destructive effects of the financial speculations on the US American housing market immediately spread all over the world through the channel of rapidly devaluating "toxic" papers of financial derivatives with doubtful, declining or evaporating market value.

D/ All cultural diversities, divisions and confrontations notwithstanding, the present day world society has at least two pillars of common culture and value-normative integration. The first one is the idea of universal rights of human individuals and the institutionalization of this idea. The second is the idea of sustainability in its environmental, economic, political and cultural dimensions and its institutionalizations. In various interpretations both ideas have been incorporated in constitutions all over the world. With various local modifications these ideas have become the core of major institutional policies and decisively guide the behavioral patterns of individuals. Thus, we witness universalization of the value-normative systems worldwide.

In historically specific terms, the governmental support to low-income households for ownership of housing in the USA as well the state support to the companies Fannie Mae and Freddie Mac was intended to achieve important economic and social effects. All these measures and institutions aimed at the practical fulfillment of the universal human right on descent housing in the context of American society as well as at achieving and maintaining economic sustainability in the country. However, there is some universal destructive potential in-built in the internally controversial global trend of universalization of value-normative systems. Financial speculations belong to this potential. On the one side, the speculations are the outcome of practicing the universal human rights of the speculators. On the other side, the financial speculations might foster the economic sustainability by facilitating the most efficient allocation of financial resources. But the effects of the financial speculations on the housing market might also turn out to be counter-productive for human rights of millions as well as for the economic, political and cultural sustainability of societal systems. This is exactly what happened in the United States and in the world after the speculative bubble of housing prices in the United States collapsed in 2008. Banks went bankrupt, the global financial system was compromised and the world plunged into the deepest recession after the Great Depression during the thirties of the last century. The global economic sustainability was undermined and the human rights of millions of individuals were massively put on a severe trial. However, one should immediately add that the non-sustainability of the American housing market was very much supported by the decision of millions of Americans to entirely focus their attention on the right to consume by neglecting the requirement to save in order to rationally fulfill the right to consume. The personal savings rate as percentage of the disposable income dropped from 11\% in 1982 to less than 1\% in 2007 (Bureau of Economic Analysis, 2008).

\section{Concluding Remarks}

The above analyzed internal tensions and contradictions inherent to the four global trends are even more complex and complicated than they were presented. The internal contradictions in the global trends under scrutiny are fostered or ameliorated due to the mutual support or tensions and conflicts between them. The upgrading of the rationality of economic organizations made necessary by the recent financial and economic crisis is largely taking place at the expense of the individualization of millions of individuals who lost their housing property or jobs in housing construction. The extreme achievements in the individualization of few who profited immensely from the speculations in the housing market came about accompanied by the spread of organizational irrationalities, undermined the legitimacy of instrumental activism and the relevance of the ideas and practices of universal human rights and sustainable development. The triumph of spreading instrumental activism in the form of speculation with financial derivatives questioned the very possibility to reach and maintain rationally organized and maintained economic stability due to the dominance of financial flows over the real economy. Another outcome became the questioning of the institutional and cultural framework for legitimate and transparent individualization as well as of the institutional background of human rights and sustainability. Last but not least, since the universal right for profitable economic activity and accumulation of property was abused at large in the processes preparing and materializing the global financial and economic crisis of 2008, the commercial rationality of major institutions turned out to be dubious, the success in individualization achieved in this way was put on doubt and the spread of instrumental activism was no more seen as morally and legally legitimate.

Given this variety of innovative analyses and conclusions, the turn from focusing on systems, structures and functions towards focusing on global trends as conceptual tools for disentangling the present day global complexity proves to be 
methodologically very rewarding. By identifying the global trends under scrutiny, their internal dynamics and tensions as well as their mutual enforcement or hindering the present day social dynamics becomes more transparent. One may reach adequate descriptions and explanations of the ongoing processes as necessary precondition for successful forecasting. This is the cognitive basis for well substantiated diagnoses of our times. In addition, this is the promising basis for efficient decisions and actions focused on the management of the controversial evolution of four global trends and of their controversial mutual influences.

\section{References}

Bauman, Z. (2001). The individualized society. Cambridge: Polity Press.

Bayer, P., Geissler, C., \& Roberts J. W. (2011). Speculators and middlemen. Cambridge MA: National Bureau of Economic Research. http://www.nber.org/papers/w16784.

Beck, U. (1986). Risikogesellschaft: Auf dem Weg in eine andere Moderne. Frankfurt am Main: Suhrkamp.

Beck, U., \& Beck-Gernsheim, E. (2002). Individualization: Institutionalized individualism and its social and political consequences. London and Thousand Oaks, Calif.: SAGE.

Bradford, C. I., \& Linn, J. E. (2011). A history of G20 summits: The evolving dynamics of global leadership', Journal of Globalization and Development, 2(2), 1-21.

Bradford, C. I., \& Lim, W. (Eds.). (2011). Global leadership in transition. Washington, D. C.: Brookings Institution Press.

Braudel, F. (1973). Capitalism and material life. Translated from French by M. Kochan. London: Weidenfeld and Nicholson.

Braudel, F. (1982). On history. Translated from French by S. Mathews. Chicago: University of Chicago Press.

Bureau of Economic Analysis (2008). Personal saving rate january 11959 to 2007. Washington D.C.: US Department of Commerce. http://research.stlouisfed.org/fred2/data/PSAVERT.txt.

Chase-Dunn, C. (2006). World-systems theorizing. In J.H.Turner (Ed.) Handbook of sociological theory, 589-612. New York and Berlin: Springer.

Crichton, J. (2010). The discourse of commercialization: A multi-perspectived analysis. Basingstoke, etc.: Palgrave Macmillan.

Dahms, H. F., \& Hazelrigg, L. (2010). Theorizing the dynamics of social processes. Bingley: Emerald.

Delaney, K. (2009). Approaches to uncertain futures. In G. Bamme \& M. Smithson (Eds.) Uncertainty and risk: Multidisciplinary perspectives ( pp. 137-146). London and Sterling, VA: Earthscan.

Due, Pernille et al. (1999). Social relations: Network, support and relational strain. Social Science \& Medicine, 48 (5), March: 661-673.

Farrar, J. H., \& Mayes, D. G. (Eds.). (2013). Globalisation, the global financial crisis and the state. Cheltenham: Edward Elgar.

Foucault, M. (1991). Discipline and punish: The birth of the prison, translated by Sheridan, A. Harmondsworth: Penguin Books.

Garriga, C., Gavin W. T., \& Schlagenhauf, D. (2005). Recent trends in homeownership. Federal Reserve Bank of St. Louis Review. September/October, 397-411.

Grober, U. (2012). Sustainability: A cultural history. Totnes, Devon: Green Books.

Hazakis, K. (2012). Analysing the logic of international monetary cooperation in Group-Twenty (G20) Summits. UNU-CRIS Working Papers W-2012/2. Brugge: CRIS.

Hindess, B. (1989). Political choice and social structure: An analysis of actors, interests, and rationality. Aldershot, Hants, UK, E. Elgar and Brookfield, USA: Gover.

IMF (2008). World economic outlook. September. Washington, D.C.: International Monetary Fund.

IMF (2010). World economic outlook. April. Washington, D.C.: International Monetary Fund.

Joas, H. (2013). The sacredness of the person: A new genealogy of human rights. Washington, DC: Georgetown Univ. Press.

Kirton, J. J. (2013). G20 governance for a globalized world. Burlington: Ashgate.

Mann, M. (2013). The sources of social power, Globalizations, 1945-2011. Cambridge etc.: Cambridge University 
Press.

Mannheim, K. (1947). Diagnosis of our time: Wartime essays of a sociologist. London: Kegan Paul Trench Trubner.

MarketWatch (2008). Transcript of Paulson briefing. 15 September. (http://articles.marketwatch.com/2008-09-15/news/30711799_1_capital-markets- financial- markets-stability.

Moyn, S. (2010). The last utopia: Human rights in history. Cambridge, Mass. and London: Belknap Press of Harvard University Press.

Narula, R. (2014). Globalization and technology. Interdependence, innovation systems and industrial policy. Hoboken: Wiley.

National Intelligence Council (2012). Global trends 2030: Alternative worlds. Washington, D.C.: NIC http://info.publicintelligence.net/GlobalTrends2030.pdf.

Parsons, T. (1971). The system of modern societies. Englewood Cliffs NJ: Prentice-Hall.

Paulson, H. M., Jr. (2010). On the brink: Inside the race to stop the collapse of the global financial system. New York: Business Plus.

Polanyi, K. (2001 [1944]). The great transformation: The political and economic origins of our time. Boston: Beacon Press.

Reinhart, V. R. (Ed.). (2013). No way out: Persistent government interventions in the great contraction. Washington, D.C.: AEI Press.

Richardson, M. E. J. (2004). Hammurabi’s laws: Text, translation and glossary. London: T \& T Clark International.

Roth, J. P. (2012). The logistics of the roman army at War (264 B.C. - A.D. 235). Boston, Brill.

Schimank, U., \& Volkmann, U. (Eds.). (2007). Soziologische Gegenwardsdiagnosen. Wiesbaden: VS Verlag für Sozialwissenschaften, 2 Vols., 2 ed.

Scott, R., \& Davis, G. F. (2007). Organizations and organizing: Rational, natural and open systems perspectives. Upper Saddle River, New Jersey: Pearson/ Prentice Hall.

Serapio, M. G., \& Hayashi, T. (Eds.). (2004). Internationalization of research and development and the emergence of global R \&D networks. Amsterdam: Elsevier.

Shiller, R. J. (2012). Finance and the good society. Princeton, N.J.: Princeton University Press. Standard occupational classification 2010 (2010). Washington, D. C.: Bureau of Labor Statistics. http://www.bls.gov/soc/major_groups.htm.

Starbuck, W. H., Holloway, S., Whalen, P. S., \& Tilleman, S. G. (2008). Organizational learning and knowledge management. Cheltenham, Glos, UK and Northampton, MA: Edward Elgar.

Statista (2011). Total home mortgage liabilities of U.S. households and nonprofit organizations 1990 to 2010. http://www.statista.com/statistics/188162/us-houshold-and-nonprofit-organization-home-mortgage-liabilities/.

Stichweh, R. (2005). Zum Gesellschaftsbegriff der Systemtheorie: Parsons und Luhmann und die Hypothese der Weltgesellschaft. Zeitschrift für Soziologie, Sonderheft "Weltgesellschaft", 174-185.

Stratton, G. (Ed.) (2010). Foreign investment in U.S. real estate. Current trends and historical perspective. New Jersey: The National Association of Realtors. http://www.realtor.org/sites/default/files/reports/2010/foreign-investment-in-US-real-estate-2010-06.pdf.

Suter, C., \& Herkenrath, M. (Eds.). (2012). World society in the global economic crisis. Berlin: Lit and London: Global.

The Telegraph (2008). 'Financial crisis: US will lose superpower status, claims German minister'. 25 September. (http://www.telegraph.co.uk/finance/financialcrisis/3081909/Financial-Crisis-US-will-lose-superpower-status-clai ms-German-minister.html.

Torry, M. (2005). Managing God's business: Religious and faith-related organizations and their management. Aldershot and Burlington: Ashgate.

Turkel, G. (2005). Talcott Parsons: The social relations of individualism and economy. Sociological Focus, 38(1), 65-82. The Wall Street Journal (2012). Foreigners snap up properties in the U.S. 12.06.

Wallerstein, I. M. (2004). World-systems analysis : An introduction. Durham: Duke University Press.

Wilson, J. Q. (1995). Political organizations. Princeton, NJ: Princeton University Press.

WIPO PCT yearly review 2015 (2015). Geneva: WIPO. 
World Bank Database (2012a). (http://search.worldbank.org/data?qterm=World\%20capital\%20flows\&language=EN .

World Bank Database (2012b). (http://search.worldbank.org/data?qterm=World+exports\&language=EN\&format=.

\section{$(\mathrm{cc}) \mathrm{BY}$}

This work is licensed under a Creative Commons Attribution 3.0 License. 